пера»: англ. "show the white feather" - струсить (букв. «показать белое перо»), "mount the white feather" - струсить (букв. поднять белое перо). Получение белого пера в Англии и Америке обозначает обвинение в трусости. Его обычно присылают людям, уклоняющимся от воинской обязанности.

В русском языке тоже можно встретить такой фразеологизм, который не имеет эквивалента в английском: «пристал как банный лист» - данное выражение используют по отношению к крайне надоедливому, назойливому человеку. Этот оборот возник из житейских наблюдений русского народа. В баню обычно ходили с берёзовыми или другими вениками, а когда парились, хлестали ими себя. Листочки отрывались от веника и приставали (прилипали) к телу.

Образы, обнаруженные в английских и русских ФЕ, выражающие состояние человека в целом классифицируются одинаково. Это связано с тем, что подсистемы ФЕ, выражающих состояние человека двух сравниваемых языков, формируются в антропоцентрической парадигме преимущественному описанию человека через его эмоции, чувства, состояния.

$$
\text { *** }
$$

1. Никифоров А. С. Эмоции в нашей жизни. Изд. 2-е. - М.: «Сов. Россия», 1978.-278 с.

2. Кунин А.В. Курс фразеологии современного английского языка . - М.:Высш. шк., Дубна: Изд. центр "Феникс", 1996-381 с. Англо-русский фразеологический словарь/Сост. А. В. Кунин. - М., 1956.-1456 c.

3. Кунин А.В. Англо - русский фразеологический словарь, 4 изд., доп. и перераб. -М, 1984г.

4. Молотков А.И. (ред.) Фразеологический словарь русского языка. -Москва: Советская энциклопедия, 1968. - 543 с

Хутова Э.Р., Чочаева С.Д.

Концепт «деньги» в паремиологическом пространстве английской и русской языковой картины мира

Кабардино-Балкарский государственный университет (Россия, Нальчик)

doi: $10.18411 / s p c-26-05-2020-08$

idsp: sciencepublic-26-05-2020-08

Одним из эффективных способов вербализации концепта «деньги» является анализ языковой репрезентации паремиологическими средствами языка, так как именно в пословицах и поговорках отражен исторический опыт, менталитет, быт и культура народа, в них заключена национальная и культурная специфика народа. Пословицы служат универсальными и уникальными ориентирами человеческой деятельности.

Пословицы и поговорки возникли благодаря традициям, обычаям и поверьям английского и русского народов: в этом их особенность. А также они были созданы на основе различных реалий и фактов истории. В целом, пословицы и поговорки - это проявление мудрости народа и отражение национальной языковой картины мира.

Сравнительное исследование языковой ментальности на материале пословиц предполагает, в первую очередь, реконструкцию соответствующих пословичных картин мира и их сопоставление при опоре исключительно на факты языка, так как именно в языке находят своё отражение причины формирования той или иной языковой ментальности, что обуславливается историческими, психологическими, психолингвистическими и другими данными.

При сравнении пословиц разных языков происходят сравнения языковых изображений мира, проявления разных языковых ментальностей.

О становлении культурного концепта «деньги» в языковом сознании этноса свидетельствуют многие паремиологические словари. 
Материалом для исследования паремиологического представления концепта «деньги» послужили извлечения из таких словарей, как: «Пословицы русского народа» В.И. Даля (2000), «Русско-английский словарь пословиц и поговорок» С.С. Кузьмина (1996), «Толковый словарь английских пословиц» Р.Райдаута, К. Уиттинга (1997), «Англо-русский словарь» В.К. Мюллера (1988).

Особенностью пословиц рассматриваемой тематики является присутствие в них, за редким исключением, наименований денежных знаков, причём эти наименования используются в прямом смысле, что значительно облегчает выявление направления ассоциативных связей между концептом «деньги» и другими концептами.

Проанализировав пословицы и поговорки английского народа, отмечаем, что в английском языке центральное место в пословичном поле занимают пословицы, прославляющие всепобеждающую силу денег: Money is the only monarch; Money reigns the world (деньги правят миром); Money is power (деньги - сила); Money is Lord (деньги бог); Money is attraction (деньги - притяжение). К ним непосредственно примыкают пословицы о созидательной, побуждающей к действию силе денег: Money makes the mare to go (за деньги и кляча поскачет); Money makes money (деньги делают деньги); Money makes the old wife trot (деньги заставляют и старую жену торопиться, бежать рысью); Money makes the pot boil (деньги заставляют и котёл закипать).

Пословицы с нейтральным компонентом «деньги», объединяющиеся в группы по происхождению, текучести, трате, воздействию на человека, занимают второе по значимости место: Money is round and rolls away (деньги круглые и катятся прочь); Money is a good servant and a bad master (деньги хороший слуга и плохой хозяин); Money has no smell (деньги не пахнут).

Третье по количеству пословиц место в пословичном поле «тоney» занимают пословицы, повествующие о бережливости. К ним, в первую очередь, относятся пословицы, построенные по одной и той же семантической модели - из малого количества денег слагается большое количество: Penny and penny laid up will be many (пенни прикреплённый к пенни будет много); A penny saved is a penny gained (пенни сбережённое всё равно, что пенни заработанное); Who will not lay up a penny shall never have money (кто не будет откладывать пенни, никогда не будет иметь деньги); Take care of the pence and the pound will take care of themselves (позаботься о пенсах, а уж фунты стерлингов сами о себе позаботятся); A penny more buys the whistle (деньга деньгу наживает).

Закрепление в сознании англичан высокого стандарта образования, его важного места в системе ценностей нашло проявление в пословице: Money spent on the brain is never spent in vain (деньги, истраченные на образование, никогда даром не пропадают).

Проанализировав пословицы и поговорки в русском языке отметим, что центральное место занимают группы пословиц, характеризующие источник денег, их трату, текучесть и другие характеристики: Деньги, что вода; Деньги - наживное дело; Деньги что галки: всё в стаю собираются; Деньги пух - только дунь на них - и нет; Деньги - гость; сегодня нет, а завтра горсть.

Пословицы, связанные с бережливостью, занимают второе место в русском пословично-поговорочном фонде. Следует бережливо относиться к деньгам, рассчитывать и планировать расходы. Для того чтобы накопить крупную сумму, следует экономно тратить деньги: Копейка рубль бережёт; Рубль иел копейкой; Грош к грошу оно и капитал; Не было ни гроша, да вдруг алтын; Копейка к копейке проживёт и семейка; Без нужды живёт, кто деньги бережёт.

Третье по количеству пословиц место занимают пословицы, отрицательно оценивающие отсутствие денег. Без денег воду пить; Без денег - бездельник; Без денег везде худенёк. Есть пословицы, которые отрицательно оценивают излишек денег: Грехов много, где денег вволю. 
Важным вопросом, решаемым в паремиологии русского народа, является определение ценностей человеческой жизни, что нашло отражение в пословицах: $У$ его хозяйки балакиръ без вести пропал (т.е. 'зарыт тайком с деньгами'); Денег нет - перед прибылью —лишний грош перед гибелью; Ростовщики на том свете калёные пятаки гольми руками считают.

Таким образом, мы видим, что с одной стороны, деньги - сила, с другой - они обретают власть и над теми, кто ими владеет, то есть это корень многих бед и разновидность рабства. Деньги сродни мудрости, в то же время большое богатство глухо к доводам рассудка. Деньги и добродетель не всегда уживаются вместе. А в русском пословично-поговорочном фонде концепт «деньги» способствует не только выражению чувств, реакций, проявлению эмоциональной жизни человека в целом, но и формирует ценностную картину мира, поскольку даёт оценку предметов по этическим и эстетическим нормам данного языкового коллектива, квалифицирует определённые свойства и проявления личности, соотнося их как с положительной, так и с отрицательной оценкой, и принадлежит выразительному фонду языка, который противостоит номинативному.

В английском и русском языках выражена мысль о том, что деньги сами по себе не могут принести внутренний покой, счастье и удовлетворение. Однако и в бедности человек не может найти довольства, радости и смысла жизни. Мудрость подсказывает, что решение этой дилеммы, с которой столь часто сталкивается человек, состоит в стремлении стать такой личностью, которая уважаема сама по себе и в то же время притягивает к себе деньги, поскольку истинное богатство состоит в наличии целого комплекса условий, включающих в себя и здоровье, и финансовое благополучие, и целеустремленность, и трудолюбие, и усердие, и знание, и нравственность, и добросердечие, и веру, и любовь, и внутренний покой, и духовность. Однако в менталитете каждого народа определяется и разное содержание одного и того же понятия «деньги», благодаря чему картина мира приобретает национальноспецифическую окраску, как в плане выражения, так и в плане содержания. Мы полагаем, что национально специфическое содержание концепта «деньги» обусловлено различным опытом познания действительности и особенностями оценочной деятельности того или иного народа.

$$
* * *
$$

1. Даль В.И. Пословицы русского народа. М.: ОЛМА - ПРЕСС, 2000г.

2. Кузьмин С.С., Шадрин И.Л. Русско-английский словарь пословиц и поговорок. - Спб., 1996.

3. Мюллер В.К. Англо-русский словарь. М.: Русский язык, 1988.

4. Райдаут Р., Уиттинг К. Толковый словарь английских пословиц. Спб., 1997.

\section{Ryabko Y.I. \\ Hermeneutical method as the analysis of a literary text and its translations}

Pacific State University (Russia, Khabarovsk)

doi: $10.18411 /$ spc-26-05-2020-09

idsp: sciencepublic-26-05-2020-09

Today literary translation is no longer treated as a mere linguistic phenomenon as it involves linguistic as well as cultural processes. Literary translation is the harmonious interaction of the two languages, literatures and cultures. The translator's actions are determined not only by language and speech styles, stylistic norms etc., they are also regulated by the rules and concepts of the source and target cultures, the standards of literary communication, the vision and understanding of a literary work, personal skills and preferences of its translator. The analysis of the systems of meanings that fill the source and 